\title{
Poglądy M. Ossowskiej na koncepcje moralności a pojęcie sprawiedliwości
}

DOI: http://dx.doi.org/10.12775/RF.2016.006

\section{Wprowadzenie}

W większości prac zdających sprawę z pojmowania sprawiedliwości wymienia się pojęcie sprawiedliwości rozumianej jako zwieńczenie wszystkich cnót, utożsamianej z doskonałością moralną. Przeciwstawia się je pojęciu sprawiedliwości polegającej na świadczeniu każdemu tego, co mu się należy (czyli kierowaniu się zasadą suum cuique) ${ }^{1}$. W związku z tym rozróżnieniem mówi się zwykle o prostym przeobrażeniu historycznym pojęcia sprawiedliwości. Współczesne koncepcje sprawiedliwości nawiązują na ogół do formuły suum quique, natomiast szersze pojęcie sprawiedliwości jest oceniane jako już nieaktualne, zbyt szerokie, a przede wszystkim - jako pojęcie o całkowicie innym rdzeniu treściowym niż pojęcie sprawiedliwości współczesne².

Głównym celem niniejszego artykułu jest rozważenie tej dystynkcji w kontekście wyróżnionych przez Marię Ossowską nurtów pojmowania moralności, tzw. felicytologii, perfekcjonistyki i nurtu solidarnościowe-

1 Pełniejsze brzmienie tej formuły to: iustitia est constans et perpetua vuluntas ius suum cuique tribuendi (sprawiedliwość to stała i niezmienna wola oddania każdemu należnego mu prawa). Jej autorstwo przypisuje się najczęściej rzymskiemu prawnikowi Ulpianowi, lecz pojawiała się ona już we wcześniejszych rozważaniach o sprawiedliwości. Szerzej o pojmowaniu sprawiedliwości w podrozdziale pt. Pojęcie sprawiedliwości niniejszego artykułu.

2 Por. np. K. Ajdukiewicz, O sprawiedliwości, w: idem, Język i poznanie. Wybór pism z lat 1920-1939. Państwowe Wydawnictwo Naukowe, Warszawa 1985, t. 1, s. 366. 
go, co pozwala, jak sądzę, sformułować trafniejszą ocenę wskazanego rozróżnienia.

Najpierw przedstawię Ossowskiej koncepcję trzech nurtów moralności, potem zastanowię się, jak rzutuje ona na problematykę sprawiedliwości, na zasadność stosowania szerszego pojęcia sprawiedliwościª

\section{Ossowskiej nurty myśli moralnej}

Wyróżnienie trzech nurtów myśli moralnej, felicytologii, perfekcjonistyki oraz nurtu solidarnościowego, uzasadnia M. Ossowska następująco. W pojęciu moralności połączyły się w trakcie dziejów różnego typu kwestie. Ponieważ mówiąc dzisiaj o moralności, mówimy o czymś bardzo skomplikowanym, warto zatem pogrupować pewne zagadnienia i postawy, by uniknąć nieporozumień wynikających z pomieszania pojęćt.

W ramach nurtu pierwszego, tzw. felicytologii, a więc higieny życia duchowego, mieszczą się zagadnienia koncentrujące się wokół osobistego szczęścia i cierpienia. Rozpatruje się w tym nurcie głównie następujące kwestie: Co zapewnia człowiekowi szczęście? Jak można uniknąć cierpień, jak przezwyciężać te cierpienia, których uniknąć się nie da? Celem etyka (etyki) w tym nurcie jest swoista terapia, polegająca na leczeniu objawów ${ }^{5}$. Zadanie to realizują choćby starożytne systemy etyczne np. epikureizm czy stoicyzm 6 .

3 Niektóre $\mathrm{z}$ tez prezentowanych w niniejszym tekście miałam okazję wygłosić na polsko-słowackiej międzynarodowej konferencji naukowej „Przemiany w nauce, filozofii, kulturze i moralności. Historia - współczesność - perspektywy” dnia 6 maja 2009 w Międzybrodziu Żywieckim.

4 M. Ossowska wyróżniła omawiane nurty najpierw w artykule pt. Trzy nurty w moralności (w: M. Ossowska, O człowieku, moralności i nauce. Miscellanea. Państwowe Wydawnictwo Naukowe, Warszawa 1983, s. 300-309) określając je jako: 1) nurt mądrości życiowej 2) nurt perfekcjonistyczny 3) nurt społeczny. Problematyka została rozwinięta w dziele: eadem, Podstawy nauki o moralności. Państwowe Wydawnictwo Naukowe, Warszawa 1966, np. s. 345-354. Por. J. Dudek, Problem unaukowienia etyki. Teoretyczne i normatywne aspekty twórczości Marii Ossowskiej. Oficyna Wydawnicza Uniwersytetu Zielonogórskiego, Zielona Góra 2012.

5 Np. Epitekt pouczał, jak godnie znosić wygnanie, ale nie interesował się tym, jak można by urządzić społeczeństwo, by przypadków wygnania nie było. Dawniej, głównie w starożytności, troska o higienę życia duchowego, o zdrowie duszy należała właśnie do mędrca, filozofa. To, co nazywano mądrością życiowa, było właśnie pewnym „znawstwem w zakresie szczęśliwości i cierpienia”. Później zaczęto "leczyć" cierpienie głównie przez usuwanie jego przyczyn, co jest zadaniem lekarzy, działaczy społecznych itp. Ossowska stwierdza jednak, że mędrzec objawowo leczący cierpienie nadal jest potrzebny, gdyż np. przyczyny niektórych cierpień są nieusuwalne, jak nieusuwalna jest śmierć. M. Ossowska, Podstawy..., op. cit., s. 349-350.

6 Ossowska podkreśla, że „,nie pogoń za uciecha, jak to sobie wyobraża laik, lecz recepta na cierpienie stanowiła centralny przedmiot zainteresowań epikureizmu". 
Można dostrzec nawiązanie do felicytologii również filozofii współczesnej - np. u klasyków utylitaryzmu7. Mimo to, jak zauważa Ossowska, nazwa etyka coraz częściej bywa zastrzeżona tylko dla pozostałych dwóch nurtów, na ogół rezygnuje się z nazywania felicytologii etykąa

Nurt drugi, a więc perfekcjonistyka, obejmuje zainteresowania etyczne związane z doskonałością osobista, z własnym poziomem, aspiracjami, godnością. Etyka w tym nurcie poszukuje odpowiedzi na pytanie, czego należy oczekiwać od człowieka doskonałego. Przede wszystkim chodzi o opisywanie wzorów życiowych, przy czym czasem są to wzorce bezimienne, czasem mamy do czynienia z konkretnymi postaciami historycznymi 9 .

$\mathrm{Z}$ aspiracjami perfekcjonistycznymi wiąże się pewna elitarność, jak wyraża się Ossowska - arystokratyzm duchowy. Łączą się one bowiem z rzeczami rzadkimi i trudnymi, z izolacją od szarego tłumu bez ambicji ${ }^{10}$. Typowo perfekcjonistyczna jest według Ossowskiej na przykład I. Kanta koncepcja obowiązku jako czynu dokonywanego wbrew skłonnościom. W jego stylu myśli obowiązek musiał być rzeczą trudną a idąc po linii skłonności nie byłby takim ${ }^{11}$.

$\mathrm{Z}$ ocenami moralnymi splatają się często w perfekcjonistyce oceny pozamoralne, np. estetyczne, może nawet istnieć problematyka perfekcjonistyczna niebędąca $\mathrm{w}$ ogóle problematyką moralną. Wzorowi przyznaje się wymiar moralny, głównie wtedy, gdy ma on składniki w postaci własności podlegających ocenie moralnej, ale ważne są również motywy, ze względu na które decydujemy się na dany wzór ${ }^{12}$.

Nurt trzeci, tzw. solidarnościowy, nazywany dziś przez niektórych etyką właściwą zajmuje się higieną współżycia. Chodzi o nurt dominujący już od czasów nowożytności. Celem etyki w tym nurcie jest uregulo-

W stoicyzmie chodzi z kolei o „asekurowanie się przed cierpieniem” przez odbieranie wartości wszystkiemu, czego możemy zostać pozbawieni i poprzez przywiązywanie wagi wyłącznie do tego, czego los nie może nam odebrać. Ibidem, s. 347-348.

7 Por. S. Dziamski, Wykłady z nauki o moralności, Wydawnictwo Naukowe Instytutu Filozofii Uniwersytetu im. Adama Mickiewicza, Poznań 2000, s. 42-45. Zob. N. White, Filozofia szczesścia. Od Platona do Skinnera, tłum. M. Chojnacki, WAM, Kraków 2008.

8 M. Ossowska, Podstawy..., op. cit., s. 359. Kwestie związane ze sprawiedliwością podejmowane przeze mnie w niniejszym tekście również wiążą się głównie z kolejnymi nurtami. P. Smoczyński (Maria Ossowska o pojęciu moralności, „Etyka” 2005, nr 38, s. 166) określa te trzy nurty jako „odmienne i czasowo odległe sposoby pojmowania moralności".

9 Ibidem, s. 350-351.

10 Por. W. Zieliński, Bocheńskiego zachęta do filozofii politycznej niepoprawności, „Filo-Sofija" 2013, nr 21, s. 207.

11 M. Ossowska, Podstawy..., op. cit.., s. 350-351. Por. L. Stevenson, Kant on Freewill, Grace and Forgiveness. „Diametros” 2014, nr 39, s. 130.

12 M. Ossowska, Podstawy..., op. cit., s. 353. 
wanie współżycia ludzi. Za szczególnie czysty przykład tak pojętej etyki uważa Ossowska etykę T. Hobbesa, którego system etyczny wychodzi z naczelnej zasady zapewnienia ludziom pokojowego współżycia ${ }^{13}$.

Z solidarnościową koncepcją moralności wiąże się przekonanie, że nie ma moralności bez współżycia ludzi, że moralność jest ściśle związana z relacjami między ludźmi. (Tym nurt solidarnościowy różni się zasadniczo od pozostałych nurtów, gdyż zwalczać cierpienie lub dbać o doskonałość można także w izolacji). Często zagadnienia podejmowane $\mathrm{w}$ nurcie solidarnościowym wiążą się z kwestiami dotyczącymi całego społeczeństwa, prawa, polityki, jednak nie zawsze. $Z$ etyką nurtu solidarnościowego mamy do czynienia każdorazowo, gdy pytamy ",jak postępować, aby innym było z nami dobrze?"14.

Należy zauważyć, że nie każde zagadnienie etyczne należy do jednego tylko nurtu, niektóre można rozpatrywać nawet z punktu widzenia wszystkich trzech. Na przykład opanowywanie namiętności bywa uważane za sposób jednocześnie na szczęście, własną doskonałość i harmonijne współżycie; kradzież można krytykować z pozycji solidarystycznych, a więc powołując się na wyrządzoną krzywdę i próbując wywołać u sprawcy żal, bądź też z pozycji perfekcjonistycznych, wskazując na jej degradujący charakter i apelując na poczucie wstydu. W myśli etycznej występowały też próby łączenia tych trzech nurtów - wysuwano w związku z tym poglądy, że kto pracuje dla szczęścia wspólnego, pracuje jednocześnie dla szczęścia własnego, że cnota i szczęście to jedno lub że wszelkie grzechy przeciw dobremu współżyciu to czyny jednocześnie degradujące człowieka ${ }^{15}$. Ossowska zauważa też: „W życiu potocznym przeskakujemy nieustannie $\mathrm{z}$ jednego $\mathrm{z}$ tych toków myśli w drugi. Kto obrzydza kradzież, powołując się na krzywdę wyrządzoną, na naruszone tym uczynkiem zaufanie wzajemne - ten jest $\mathrm{w}$ systemie moralności społecznej. Kto ją obrzydza, powołując się na jej degradujący charakter, na to, jak nie licuje ona z naszą godnością osobista, odwołuje się do do motywacji perfecjonistycznej"16.

Wydaje się, że główne błędy w rozważaniach etycznych wynikające z niedoceniania wyróżnionych toków myśli to: 1) bezwiedne bądź celowe utożsamianie wybranego nurtu z ogółem moralności i skupianie się tym samym tylko na jednej stronie moralności ${ }^{17}$ oraz 2 ) ocenianie koncepcji należących do jednego z nurtów z punktu widzenia innego nurtu

13 Ibidem, s. 354.

14 Ibidem.

15 Ibidem, s. 355-358.

16 M. Ossowska, Trzy nurty..., op. cit., s. 306.

17 „Ci, którzy tkwili w jednym z wymienionych trzech toków myśli, bywali często skłonni monopolizować nazwę moralność wyłącznie dla siebie. Jak np. słyszy się czasem od ludzi zainteresowanych wyłącznie regułami moralnymi jako regułami normującymi współżycie, że dociekania etyczne starożytności, które tak sprawy mo- 
(np. krytyka umartwienia i pokuty, a więc praktyk doskonalących, jako nie sprzyjających szczęściu; ocenianie czystości płciowej - cnoty zdobiącej, cnoty w stylu perfekcjonistycznym - z punktu widzenia walorów społecznych). Oba typy błędów można dostrzec w rozważaniach o sprawiedliwości ${ }^{18}$.

\section{Pojęcie sprawiedliwości}

Z terminem sprawiedliwość wiąże się dziś wiele różnorodnych intuicji, toteż treść i desygnaty pojęcia sprawiedliwości są zróżnicowane. Różnice w rozumieniu sprawiedliwości wiążą się z niejednolitym określaniem np. statusu ontologicznego, nośników sprawiedliwości, cech sprawiedliwości, podmiotów i przedmiotów działań sprawiedliwych, a także ze sposobami definiowania sprawiedliwości lub z własnościami przypisywanymi pojęciu sprawiedliwości ${ }^{19}$.

W pracach zdających sprawę z wielości ujęć sprawiedliwości, różne pojęcia sprawiedliwości traktowane są zwykle jako występujące obok siebie. Co więcej, przyjmujemy, że wyłania się z zastanych koncepcji coś, co można określić mianem ogólnego pojęcia sprawiedliwości - chwytającego to, co wspólne w odmiennych pojęciach, stosowanych w różnorodnych sytuacjach (wspólna treść wyraża się co najmniej w przytoczonej wyżej formule suum cuique $)^{20}$.

ralności nie pojmowały, w ogóle nie znały koncepcji moralnych, będących właściwie dopiero wytworem czasów nowożytnych". Ibidem, s. 307.

18 Zob. ibidem, s. 354-355.

19 Szerzej o tym: H. Šimo, O sprawiedliwości. Koncepcja inspirowana wynikami polskiej filozofii analitycznej. Wydawnictwo Aureus, Kraków 2009, rozdział I.

20 Chyba każdą definicję sprawiedliwości można uznać za propozycję podstaw orzekania należności, jedną z odpowiedzi na pytanie „Co się należy?”. Formułą trafnie wyrażającą część wspólną większości odpowiedzi na to pytanie można uznać Ch. Perelmana zasadę sprawiedliwości formalnej, zgodnie z którą trzeba jednakowo traktować osoby, które są pod jakimś względem jednakowe (równość miar). Obie te zasady można zatem zaliczyć do najogólniejszych zasady sprawiedliwości, są zatem ogólnikowe, ubogie treściowo, domagają się konkretyzacji (jej wynikiem są właśnie różne koncepcje sprawiedliwości). O relacjach między formułą suum cuique i zasadą sprawiedliwości formalnej, a także np. Ajdukiewicza zasadą równej miary - zob. H. Šimo: O sprawiedliwości..., op. cit., s. 56-60; H. Kabot: Najogólniejsze zasady sprawiedliwości. „Ruch Filozoficzny „, 2006, nr 1 (t. LXIII), s. 57-61.

W związku ze wspólnym rdzeniem treściowym różnych pojęć sprawiedliwości mówimy, że termin „sprawiedliwość" jest wprawdzie wieloznaczny, ale jego wieloznaczność nie jest wieloznacznością słownikową. W tej najprostszej, leksykalnej odmianie wieloznaczności wyrażeniu przysługują całkowicie różne znaczenia orzekane w różnych zakresach, tj. o różnych desygnatach. W przypadku "sprawiedliwości” sytuacja jest inna. Termin „sprawiedliwość”, mimo różnych dziedzin jego stosowania, jest używany w odmiennych, lecz pokrewnych znaczeniach. Ten rodzaj wielo- 
Pojęcie sprawiedliwości, które wywodzi się ze wspomnianego we wprowadzeniu rozróżnienia, czyli pojęcie sprawiedliwości jako doskonałości moralnej, jest traktowane jako pojęcie całkiem odmienne. Jak zasygnalizowałam wcześniej, przedstawia się je jako przestarzałe, wskazuje się, że pozostaje ono w całkiem innej relacji do pojęcia moralności niż pojęcie współczesne, a przede wszystkim podkreśla się, że ma ono inny rdzeń treściowy, czyli że nie da się go podciągnąć pod owo ogólne pojęcie sprawiedliwości. Jak się wydaje, poglądy M. Ossowskiej na koncepcje moralności skłaniają do zakwestionowania tych ocen ${ }^{21}$.

Rozważana dystynkcja ma źródło w pochodzącym od Arystotelesa rozróżnieniu sprawiedliwości szczegółowej i ogólnej²2. Szersze rozumienie sprawiedliwości rzeczywiście jest dziś oceniane jako mało aktualne, co potwierdzają słowniki, w których zanika takie jej pojmowanie ${ }^{23}$. Trzeba jednak mieć na uwadze, że takie ujęcia są dziś na ogół oceniane jako za szerokie i już archaiczne z punktu widzenia nurtu moralności dziś dominującego, czyli nurtu solidarnościowego. Skazywane na zapomnienie pojęcie sprawiedliwości jest przy tym skonstruowane $w$ ramach perfekcjonistyki, która obecnie nie dominuje, jednak nadal w ocenach moralnych się pojawia. Nie należy więc pomijać tej koncepcji sprawiedliwości, gdyż nadal spotyka się ją i to nie tylko w tekstach religijnych (np. w Biblii) i u starożytnych filozofów (np. u Platona), ale również w np. w filozofii Kanta czy W. Tatarkiewicza. Ponadto, są one o wiele bliższe klasycznemu pojmowaniu sprawiedliwości niż się na pierwszy rzut oka wydaje ${ }^{24}$.

znaczności jest nazywany wieloznacznością systematyczną (S. Blackburn, Oksfordzki słownik filozoficzny, red. nauk. J. Woleński, tłum. C. Cieśliński, P. Dziliński, M. Szczubiałka, J. Woleński, Książka i Wiedza, Warszawa 1997, s. 430-431).

21 Warto zaznaczyć, iż nie było to intencją M. Ossowskiej - widać to w jej rozważaniach o sprawiedliwości. Zob. M. Ossowska, Normy moralne. Próba systematyzacji. Państwowe Wydawnictwo Naukowe, Warszawa 1985, rozdz VII pt. Normy moralne strzegace sprawiedliwości.

22 Arystoteles, Etyka nikomachejska, tłum. D. Gromska, PWN, Warszawa 1956, s. $160-161$.

23 Por. K. Ajdukiewicz, O sprawiedliwości..., op. cit., s. 366. Z. Ziembiński (O pojmowaniu sprawiedliwości, „Wszechnica Myśli Etycznej, Fundacja Biblioteki Etycznej”, Instytut Wydawniczy „Daimonion,,, Lublin 1992, s. 21-22) porównuje określenia sprawiedliwości w następujących słownikach: tzw. „warszawski,, Słownik języka polskiego (1915 r., jako odpowiedniki „sprawiedliwości,, są wskazane m.in. „słuszność,,,

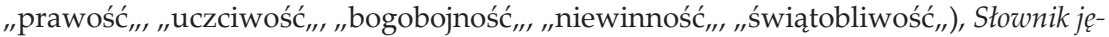
zyka polskiego PAN (1966 r., wyżej wymienione znaczenia określone są jako „dawne,"), Słownik poprawnej polszczyzny Stanisława Szobera (1973 r., uwzględnione są tylko ślady szerokiego rozumienia sprawiedliwości), Słownik języka polskiego PWN (1981 r., szersze pojęcie sprawiedliwości w ogóle nie jest uwzględnione).

${ }_{24}$ Por. M. Nalepa, Sprawiedliwość jako pojęcie transcendentalne Immanuela Kanta i Simone Weil wyobrażenie o warunkach umożliwiajacych życie polityczne, „Przegląd Humanistyczny „, 4, 1998, s. 122. W. Tatarkiewicz (O doskonałości, PWN, Warszawa 1976, s. 31) 
Gdy chodzi o relacje między pojęciami sprawiedliwości i moralności, potocznie pojęciu czynu sprawiedliwego przypisujemy zakres znacznie węższy od zakresu pojęcia czynu moralnie dobrego. Nie uznaje się wszystkiego, co jest etycznie dodatnie, za sprawiedliwe, a wszystkiego, co etycznie ujemne, za niesprawiedliwe. Ta potoczna ocena jest trafna, gdy intuicyjne pojęcie moralności zestawiamy ze sprawiedliwością ściśle pojęta, odnoszoną tylko do „typowych dóbr, które są w sensie dosłownym przedmiotem wymiany lub podziału" 25 .

Jednak nie wszystkie koncepcje sprawiedliwości koncentrują się na zasadach dystrybucji dóbr ekonomicznych. W myśl poglądu, że sprawiedliwość w postaci cnoty owocuje raczej rozpowszechnianiem wartości niż wycenionych dóbr ${ }^{26}$, za przedmioty świadczeń sprawiedliwych uznaje się często praktycznie cokolwiek, czemu przypisujemy wartość, dodatnią lub ujemną. Działanie sprawiedliwe może zatem dotyczyć dóbr różnorodnych ${ }^{27}$. Taka interpretacja skutkuje pojęciem sprawiedliwości o zakresie bardzo szerokim, które dotyczy m.in. dysponowania szacunkiem, miłościa, wolnością itp. Wtedy np. „zabójstwo niewinnego człowieka jest niesprawiedliwością, gdyż polega na odebraniu tego, co należy tylko do niego, a mianowicie życia" 28 .

W związku z koncepcją nawiązującą do szerokiego rozumienia dóbr można stwierdzić, że nawet $\mathrm{w}$ nurcie solidarnościowym wymaga się, by postępowanie aprobowane moralnie było sprawiedliwe. Tak więc również $\mathrm{w}$ tym nurcie pojęcie moralności zakresowo pokrywa się z nawiązującym do szerokiego rozumienia dóbr pojęciem sprawiedliwości, podobnie jak ma to miejsce $\mathrm{w}$ nurcie perfekcjonistycznym. Zatem sprawiedliwość może być w obu nurtach tratowana jako cnota uniwersalna. Nie dostrzegamy tego wtedy, gdy nie zwracamy uwagi na różnorod-

zalicza do synonimów nazwy „doskonały" nazwę „sprawiedliwy” - obok „święci”, "dobrzy", „bez skazy”.

25 Ustalenia odnoszą sią do moralnych koncepcji sprawiedliwości (propozycje orzekania należności podyktowane przez czyjeś poczucie słuszności moralnej, jak ujmuje to K. Ajdukiewicz). Relacje komplikują się, gdy bierze się pod uwagę tzw. sprawiedliwość prawną („legalną“ w nomenklaturze Ajdukiewicza), której zasady określane są przez literę, bądź ducha prawa pozytywnego. Zob. K. Ajdukiewicz: O sprawiedliwości, s. 368-369. Nie można bowiem a priori oceniać wartości moralnej postępowania zgodnego z jej postulatami. Por. Ch. Perelman: O sprawiedliwości, tłum. W. Bieńkowska. Państwowe Wydawnictwo Naukowe, Warszawa 1959, s. 27.

26 R. Liberkowski, Stowo wstęne, w: W. Heller, R. Liberkowski (red.), Wola sprawiedliwości, „Pisma Filozoficzne” t. LXX, Wydawnictwo Naukowe Instytutu Filozofii UAM, Poznań 2000, s. 12. Z kontekstu wynika, że chodzi o wartości węziej pojęte np. wartości moralne.

27 Zob. np. K. Ajdukiewicz, O sprawiedliwości..., op. cit., s. 366-371; Z. Ziembiński: O pojmowaniu..., op. cit., s. 63; R. Kleszcz, Co to znaczy „sprawiedliwość"? , „Filozofia Nauki" 1999, nr 1-2 (25-26), s. 34.

28 H.H. McCloskey, Meta-Ethics and Normative Ethics, The Hague 1969, s. 233. 
ność koncepcji sprawiedliwości, a także nurtów moralności, przed czym „przestrzega” nas M. Ossowska.

Ostatnia, najważniejsza, kwestia wiąże się z rzekomą odmiennością rdzenia treściowego omawianego pojęcia sprawiedliwości. Pytanie brzmi, czy formuła suum cuique, nakazująca świadczyć każdemu, to, co mu się z jakiegoś względu należy, naprawdę nie obejmuje sprawiedliwości pojętej jako doskonałość etyczna?

Rozumując „w nurcie solidarnościowym” jesteśmy skłonni automatycznie ograniczać zasięg sprawiedliwości do świadczeń należnych w stosunku do innych osób. Stąd częste wnioski, że omawiana formuła nie obejmuje rozumienia sprawiedliwości jako doskonałości etycznej.

Charakterystyki sytuacji, które mogą być oceniane z punktu widzenia sprawiedliwości, uwzględniają wprawdzie na ogół dwustronność, czyli jest zaangażowanie dwu stron, przy czym jedna drugiej coś wyświadcza ${ }^{29}$. Jednak różne są koncepcje możliwych podmiotów świadczeń. W niektórych koncepcjach mogą nimi być tylko ludzie, w innych ujęciach zakresy pojęć sprawcy i adresata są jednak rozszerzone, np. na istoty nadprzyrodzone, zwierzęta, twory kulturowe ${ }^{30}$. Na ogół przyjmuje się, iż kategoria sprawiedliwości odnosi się do postępowania wobec innych podmiotów, że nie jest możliwe postępować sprawiedliwie (niesprawiedliwie) wobec samego siebie. Jednak, jak zauważa R. Ingarden, akt może mieć sprawcę i adresata w jednej osobie, o ile dochodzi do jakiegoś przeciwstawienia w danej osobie sprawcy i adresata ${ }^{31}$.

Sądzę, że gdyby solidarnościowe nastawienie „nie ograniczało" naszego postrzegania, uznalibyśmy za sprawiedliwe także cechy takie, jak umiar, męstwo, bogobojnośćc ${ }^{32}$. Postępowanie kierowane tymi własnościami zostałoby potraktowane jako świadczenie czegoś sobie lub Bogu, jako postępowanie powinne, coś, co można oceniać z punktu widzenia formuły "co się należy". Poza nurtem solidarnościowym uznaje się, że jednostce należy się coś od niej samej, a oceny z punktu widzenia sprawiedliwości odnoszą się nie tylko do innych ludzi ${ }^{33}$.

Podsumowując, wywodzący się z pism Arystotelesa podział jest zwykle traktowany jako rozróżnienie sprawiedliwości, której zasady regulują dysponowanie dobrami w zakresie stosunków międzyludzkich,

29 Zob. K. Ajdukiewicz, O sprawiedliwości..., op. cit., s. 366; R. Kleszcz, Co to znaczy..., op. cit., s. 33.

30 Por. Ch. Perelman, O sprawiedliwości..., op. cit., s. 132, J. Lipiec, Prolegomena do etyki globalnej, w: J. Sekuła (red.), Idea etyczności globalnej. Wydawnictwo Seculum, Siedlce 1999, s. 199.

31 R. Ingarden, Wykłady z etyki, Państwowe Wydawnictwo Naukowe, Warszawa 1989, s. 273.

32 Zob. J. Szczepański, O indywidualności, Instytut Wydawniczy Związków Zawodowych, Warszawa 1988, np. s. 6-7.

33 Por. J. Dudek, Problem..., op. cit., s. 198. 
i sprawiedliwości, której zasady mają zasięg szerszy - dotyczą wszelkich czynów $^{34}$. Można jednak tę drugą interpretować jako dysponowanie wszelkimi, szeroko pojętymi dobrami w stosunku do różnych podmiotów. Widać wtedy wyraźniej wspólny rdzeń obu tych pojęć sprawiedliwości: mówiąc o sprawiedliwości zawsze mamy na myśli coś, co wiąże się ze świadczeniem należnego ${ }^{35}$.

\section{Bibliografia}

Arystoteles, Etyka nikomachejska, tłum. D. Gromska, PWN, Warszawa 1956. Ajdukiewicz K., O sprawiedliwości, w: Język i poznanie. Wybór pism z lat 1920-1939, Państwowe Wydawnictwo Naukowe, Warszawa 1985, t. 1.

Blackburn S., Oksfordzki słownik filozoficzny, red. nauk. J. Woleński, tłum. C. Cieśliński, P.

Dziliński, M. Szczubiałka, J. Woleński, Książka i Wiedza, Warszawa 1997.

Dudek J., Problem unaukowienia etyki. Teoretyczne i normatywne aspekty twórczości Marii Ossowskiej, Oficyna Wydawnicza Uniwersytetu Zielonogórskiego, Zielona Góra 2012.

Dziamski S., Wykłady z nauki o moralności, Wydawnictwo Naukowe Instytutu Filozofii Uniwersytetu im. Adama Mickiewicza, Poznań 2000.

Ingarden R., Wykłady z etyki, Państwowe Wydawnictwo Naukowe, Warszawa 1989.

Kabot H., Najogólniejsze zasady sprawiedliwości, „Ruch Filozoficzny, 2006, nr 1, 2006.

Kleszcz R., Co to znaczy „sprawiedliwość”?, „Filozofia Nauki,, 1999, nr 1-2 (25-26).

Kołakowski L., O sprawiedliwości, w: Mini wykłady o maxi sprawach. Trzy serie, Wydawnictwo Znak, Kraków 2003.

Liberkowski R., Stowo wstępne, w: W. Heller, R. Liberkowski (red.), Wola sprawiedliwości, „Pisma Filozoficzne” t. LXX, Wydawnictwo Naukowe Instytutu Filozofii UAM, Poznań 2000.

Lipiec J., Prolegomena do etyki globalnej, w: J. Sekuła (red.), Idea etyczności globalnej, Wydawnictwo Seculum, Siedlce 1999.

McCloskey H.H., Meta-Ethics and Normative Ethics, Martinus Nijfoff, The Hague 1969.

Nalepa M., Sprawiedliwość jako pojęcie transcendentalne Immanuela Kanta i Simone Weil wyobrażenie o warunkach umożliwiajacych życie polityczne, „Przegląd Humanistyczny" 1998, nr 4.

34 Por. K. Ajdukiewicz, O sprawiedliwości..., op. cit., s. 366.

35 Nawet jeśli trafny jest pogląd L. Kołakowskiego, że nie w każdym przypadku orzekania sprawiedliwości trzeba zakładać, że komuś coś się należy, jest jednak pewne, że każdy taki przypadek można w kategoriach należności ująć. L. Kołakowski, O sprawiedliwości, w: idem, Mini wykłady o maxi sprawach. Trzy serie, Wydawnictwo Znak, Kraków 2003, s. 265. 
Ossowska M., Normy moralne. Próba systematyzacji, Państwowe Wydawnictwo Naukowe, Warszawa 1985.

Ossowska M., Trzy nurty w moralności, w: O człowieku, moralności i nauce. Miscellanea, Państwowe Wydawnictwo Naukowe, Warszawa 1983.

Ossowska M., Podstawy nauki o moralności, Państwowe Wydawnictwo Naukowe, Warszawa 1966.

Perelman Ch., O sprawiedliwości, tłum. W. Bieńkowska. Państwowe Wydawnictwo Naukowe, Warszawa 1959.

Smoczyński P., Maria Ossowska o pojęciu moralności, „Etyka” 2005, nr 38.

Stevenson L., Kant on Freewill, Grace and Forgiveness. „Diametros” 2014, nr 39.

Szczepański J., O indywidualności, Instytut Wydawniczy Związków Zawodowych, Warszawa 1988.

Šimo H., O sprawiedliwości. Koncepcja inspirowana wynikami polskiej filozofii analitycznej, Wydawnictwo Aureus, Kraków 2009.

Tatarkiewicz W., O doskonałości, PWN, Warszawa 1976.

White N., Filozofia szczęścia. Od Platona do Skinnera, tłum. M. Chojnacki, WAM, Kraków 2008.

Zieliński W., Bocheńskiego zachęta do filozofii politycznej niepoprawności. „Filo-Sofija" 2013/2, nr 21.

Ziembiński Z., O pojmowaniu sprawiedliwości, „Wszechnica Myśli Etycznej, Fundacja Biblioteki Etycznej”, Instytut Wydawniczy „Daimonion”, Lublin 1992.

\section{Poglądy M. Ossowskiej na koncepcje moralności a pojęcie sprawiedliwości}

\section{Słowa kluczowe}

Sprawiedliwość; moralność; normy moralne; M. Ossowska; suum cuique; felicytologia, perfekcjonistyka; nurt solidarnościowy

W większości prac o sprawiedliwości wymieniane są dwa podstawowe pojęcia sprawiedliwości. Szersze pojęcie ujmuje sprawiedliwość jako zwieńczenie wszystkich cnót - sprawiedliwość jest tu utożsamiana z doskonałością moralną. Przeciwstawia się je pojęciu sprawiedliwości polegającej na świadczeniu każdemu tego, co mu się należy (zgodnie z zasadą suum cuique, a więc - „każdemu, co mu się należy"). Rozróżnienie to jest zwykle traktowane jako wynik prostego przeobrażenia historycznego: szersze pojęcie sprawiedliwości jest postrzegane jako już nieaktualne, zbyt szerokie, a przede wszystkim całkowicie odmienne od współczesnego rozumienia sprawiedliwości. Uwzględnienie wyróżnionych przez Marię Ossowską trzech nurtów moralności pozwala na sformułowanie lepszej, trafniejszej oceny powyższego rozróżnienia. Pozwala dostrzec, że rozu- 
mując w nurcie solidarnościowym, który jest dziś najbardziej popularny, mamy tendencję do ograniczania zakresu sprawiedliwości do świadczeń w stosunku do innych ludzi. Stąd częste wnioski, że formuła suum cuique nie obejmuje rozumienia sprawiedliwości jako doskonałości etycznej. Gdyby solidarnościowe nastawienie nie ograniczało naszego postrzegania, bylibyśmy skłonni nazywać sprawiedliwymi także własności takie, jak na przykład umiar, męstwo, pobożność. Działania motywowane tymi cnotami byłyby traktowane jako świadczenia czegoś względem samego siebie lub Boga, w związku z czym mogłyby być także oceniane z punktu widzenia formuły „każdemu, co mu się należy”.

\section{Ossowska's views on concepts of morality and the notion of justice}

\section{Keywords}

Justice; morality; moral norms; M. Ossowska; suum cuique; felicitology; perfectionism; hygiene of social intercourse

Most studies of justice mention two basic concepts of justice. The broader one defines justice as a culmination of all the virtues - justice is identified with moral perfection. To this concept they oppose the narrower concept which describes justice as the rendering to each man of his due (according to the principle suum cuique which literally means "to each his own").

The distinction is usually treated as a result of simple historical transformation: a broader concept of justice is perceived as outdated, too broad, and above all - as a concept which is completely different from the second one, contemporary understanding of justice.

Considering three strands of morality understanding distinguished by Maria Ossowska allow us to formulate better, more insightful evaluation of the distinction above. We realize that considering things from the solidarity point of view, which is most popular these days, we tend to limit the extent of justice for benefits in relation to other people. Hence frequent conclusions that formula suum cuique does not include the understanding of justice as ethical perfection. If solidarity concerning strand of morality did not limit our perception, we would consider as just even such features as moderation, fortitude, piety. Actions motivated by these virtues would be treated as rendering something to person himself or to God and they could be evaluated from the point of view of the formula ", to each his own" too. 